\title{
EL EXEMPLO 51 DE EL CONDE LUCANOR (ATU 757), MIO CID Y KING LEAR: SOBERBIA, IRA, Y EL NOBLE AL QUE CIERRAN LAS PUERTAS DE SU CASA*
}

\author{
José Manuel Pedrosa \\ Universidad de Alcalá \\ jmpedrosa2000@yahoo.es
}

Para Cristina Simón

\section{El exemplo 51 de EI conde Lucanor y el cuento internacional ATU 757 (La jactancia del emperador, castigada)}

Un artículo reciente de Olivier Biaggini ${ }^{1}$ ha presentado un estado de la cuestión muy agudo, denso y renovado del exemplo 51 («Lo que contesció a un rey christiano que era muy poderoso et muy soberbioso») de El conde Lucanor de don Juan Manuel. La documentadísima monografía de Biaggini me exonera de volver a insistir acerca de muchas cuestiones de poética, tradición e interpretación de tal relato; y me libera, de paso, de tener que terciar en la controversia del lugar que ocupará este exemplo dentro de la compilación de don Juan Manuel, pues el hecho de que haga el extraño e irregular número 51 (y último) ha suscitado diferencias entre los críticos que han defendido

\footnotetext{
*Agradezco su ayuda y orientación a José Luis Garrosa, Chet Van Duzer y María Jesús Lacarra.

${ }^{1}$ Biaggini, «El ejemplo 51 de El conde Lucanor y la escritura manuelina: discurso ejemplar y concepción de texto», en Formas narrativas breves. Lecturas e interpretaciones, ed. de Carlos Alvar, San Millán de la Cogolla, Cilengua, 2014, pp. 27-59. Conviene señalar, al margen del artículo de Biaggini, que María Jesús Lacarra ha defendido que otro cuento de El conde Lucanor, el que ella titula El muerto imaginario (el cual está copiado en el llamado manuscrito P), tiene relación estructural con el que analizó Biaggini y analizaré ahora yo. Véase M. ${ }^{a}$ Jesús Lacarra, «Los copistas cuentistas: los otros ejemplos de El conde Lucanor en el códice de Puñonrostro», en «Entra mayo y sale abril»: Medieval Spanish Literary and Folklore Studies in Memory of Harriet Goldberg, ed. de Manuel da Costa Fontes y Joseph T. Snow, Newark, Delaware, Juan de la Cuesta, 2005, pp. 231-258; y M. Jesús Lacarra, «El muerto imaginario: un cuento medieval de fantasmas a la luz de la tradición», en Il confronto letterario, Supplemento al numero 60, Atti del seminario Short tales in Western European Literatures, Università di Pavia, 21-26 maggio 2012, 60 (2013), pp. 49-64.
} 
su presunto carácter original y legítimo y los críticos que lo consideran más bien postizo y sobrevenido. Biaggini revisa de manera muy ponderada toda la bibliografía crítica anterior y se inclina por que el exemplo 51 muestra analogías significativas con otras ideas y partes de la obra, lo que podría ser indicio de la autoría de don Juan Manuel:

El autor del ejemplo del rey soberbio comparte con don Juan Manuel una postura ideológica muy precisa respecto al ejercicio del poder temporal y su relación con la esfera espiritual. Por otra parte, en el marco restringido del manuscrito $\mathrm{S}$, sospecho que la presencia de este ejemplo puede relacionarse temáticamente con otra pieza que, como él, solo se encuentra en este manuscrito: me refiero al prólogo general de don Juan Manuel².

Yo no tengo datos ni cualificación para pronunciarme acerca de la autoría del exemplo 51 de El conde Lucanor, y por eso voy a limitarme a considerarlo - por razones puramente prácticas- obra juanmanuelina, y a dar a este artículo una orientación comparatista, enfrentándolo a algunos hasta ahora muy desatendidos paralelos. Seguiré así la vía que abrió el propio Biaggini, quien dedicó la parte central de su trabajo a contrastar el relato de don Juan Manuel con

el exemplum de los Gesta Romanorum que refiere la historia del emperador Joviniano; Li dis dou magnificat, poema francés de Jean de Condé (c. 12751345) compuesto sin duda en el condado de Hainaut a principios del siglo XIV; Robert of Cisyle, poema inglés anónimo anterior a 1370; y un relato en prosa que forma parte de las Novelle del toscano Giovanni Sercambi (1348-1424), obra poco posterior a 1374 en su primera versión ${ }^{3}$.

Conviene advertir, en cualquier caso, que los cuatro paralelos tipológicos medievales (uno en latín, otro en francés, otro en inglés y el último en italiano) que Biaggini eligió para el contraste con el relato de don Juan Manuel son -las limitaciones de espacio no permitían otra cosa- una muestra relativamente corta del amplio elenco de las versiones que se conocen del relato:

El cuento estudiado tuvo una tradición muy amplia en la Edad Media y hasta nuestros días. Aparece referenciado en el Index exemplorum de Frederic Tubach 4 (1894 y 3015), el tipo correspondiente se registra en el Motifindex de Stith Thompson ${ }^{5}$ (L411) y se le han dedicado varios estudios desde

\footnotetext{
${ }^{2}$ Biaggini, «El ejemplo 51», art. cit., p. 30.

${ }^{3}$ Biaggini, «El ejemplo 51», art. cit., pp. 31-32.

${ }^{4}$ Friedrich C. Tubach, Index Exemplorum: A Handbook of Medieval Religious Tales [FF Communications 204], Helsinki, Suomalainen Tiedeakatemia-Academia Scientiarum Fennica, 1969.

${ }^{5}$ Stith Thompson, Motif-Index of Folk Literature: a Classification of Narrative Elements in Folkta- 
el siglo XIX, aunque centrados todos en otras versiones que la de El conde Lucanor, especialmente en las versiones alemanas y latinas, a partir del estudio filológico de Hermann Varnhagen ${ }^{6}$. Desde finales del siglo XIX, varios eruditos han debatido sobre el origen de la historia que, según los unos, tiene que ser indio y, según los otros, sería judío. Varnhagen distingue unas cuarenta y cinco versiones en lenguas europeas, siendo la más famosa y difundida la que contienen los Gesta Romanorum -colección de exempla de finales del siglo XIII o principios del siglo XIV- que dio lugar a una rama separada, integrada por las numerosas traducciones de los Gesta a lenguas vernáculas [...].

Aunque los criterios difieren entre los estudiosos, se suelen distinguir dos ramas o familias de versiones para el cuento del monarca soberbio: la familia representada por los Gesta, en la que el monarca es un emperador y su sacrilegio un simple pensamiento blasfematorio, y la familia del magnificat, en la que el monarca suele ser un rey y su pecado consiste en prohibir un verso del poema: Deposuit potentes de sede et exaltavit humiles (dentro de esta familia, la más antigua versión conservada es alemana y data de la primera mitad del siglo XIII). Todas las versiones siguen una trama basada en la secuencia sacrilegio-castigo-enmienda-restauración ${ }^{7}$.

Personalmente, yo veo irrelevante, y creo que queda además muy fuera del alcance de nuestra ciencia, determinar si nuestro relato tiene orígenes indios o judíos - ¿y por qué no chinos o árabes o rusos o etíopes o subsaharianos?-. Nadie puede, tan a posteriori, determinar si sus raíces manarán de la tradición india, o si de la judía, o si vendrán de cualquiera otra que no cuente -por alguna razón que habrían de explicar ellos- con tanto predicamento como tienen las tradiciones india y judía entre algunos críticos y escuelas.

Más práctico que entrar en esa discusión tan estéril -y tan impregnada de los trasnochados evolucionismos de la crítica decimonónica-, creo que será señalar que existe otro artículo, tan agudo y documentado como escasamente atendido - no lo cita Biaggini-, de Jesús Menéndez Peláez, que analiza en detalle las versiones de nuestro relato escritas en español desde finales del siglo XV hasta finales del XVII. En primer lugar llama la atención Menéndez Peláez sobre la refundición inserta en la llamada Summa de san Antonio, Arzobispo de Milán, escrita en latín y atribuida a tal arzobispo, quien vivió entre 1389 y 1459. De ella manaron las adaptaciones al castellano que se hallan

les, Ballads, Myths, Fables, Mediaeval Romances, Exempla, Fabliaux, Jest-Books and Local Legends, ed. rev. y aum., 6 vols., Bloomington \& Indianapolis-Copenhague, Indiana University-Rosenkilde \& Bagger, 1955-1958.

${ }^{6}$ Hermann Varnhagen, Ein indisches Märchen auf seiner Wanderung durch die asiatischen und europäischen Litteraturen, Berlín, Weidmannsche Buchhandlung, 1882.

${ }^{7}$ Biaggini, «El ejemplo 51», art. cit., pp. 30-32. 
engastadas en un cuaderno manuscrito de finales del XVI compilado por el P. Juan Alonso Lobera -que está hoy en el archivo de la Compañía de Jesús en Loyola-, y en el Libro del reyno de Dios y del camino por donde se alcança, confirmado con ejemplos y sentencias de santos... por el Padre Doctor Pedro Sánchez de la misma Compañia (1594). Llama la atención además Menéndez Peláez sobre las versiones insertas en la Historia de los Reyes Católicos don Fernando y doña Isabel de Andrés Bernáldez - el llamado cura de los Palacios-, y en El rey don Pedro en Madrid de Tirso de Molina, y sobre las refundiciones del Auto del Emperador Juveniano, que está dentro del Códice de autos viejos, del Coloquio de la Escolástica triunfante y Babilonia nueva del P. Salas de La Compañia (1611), y de Del cielo viene el buen rey (1657) de Rodrigo de Herrera y Ribera ${ }^{8}$. Lamentablemente, ha de quedar por el momento pendiente, hasta que surja alguna oportunidad, la que se presume fructífera labor de contraste de estas versiones con las medievales.

Es importante hacer notar, también, que nuestro relato tiene -aunque tampoco lo señale Biaggini- número propio en el catálogo internacional de tipos cuentísticos de Aarne-Thompson-Uther (ATU). Se trata de ATU 757 (The Emperor's Haughtiness Punished), que ha sido resumido de este modo:

La jactancia del emperador, castigada (en el catálogo anterior, La jactancia del rey, castigada). El emperador Joviniano se cree Dios. Mientras se baña, un extranjero (o un ángel) que se parece a él le quita sus vestiduras y reina en su lugar. Cuando Joviniano regresa desnudo a su corte, nadie le reconoce, y es expulsado. En su desesperación, se pone a lamentar su jactancia de antes. Más adelante, cuando vuelve a reclamar su dignidad, es aceptado como emperador. El extranjero que había reinado en su lugar se revela como su ángel guardián y desaparece. A partir de entonces, el emperador vive de manera humilde y piadosa9.

El catálogo de Aarne-Thompson-Uther remite a una muy prolija bibliografía de los estudios y los estudiosos (el clásico Varnhagen, más Chauvin, Wesselski, Schwarzbaum, Dahlke, Müller, Curschmann, Tomkowiak...) que

\footnotetext{
${ }^{8}$ Véase Jesús Menéndez Peláez, «Teatro jesuítico: La escolástica triunfante y nueva Babilonia del P. Pedro Salas. La tradición del cuento del rey soberbio», en Teatro de palabras: Revista sobre teatro áureo, 1 (2007), pp. 123-154; y también Silvia González-Sarasa, «La producción dramática de Rodrigo de Herrera y Ribera: aproximación a su biografía y Repertorio bibliográfico», E-Humanista, 20 (2012) pp. 491-510; y, además, Maxime Chevalier, Cuentos folklóricos españoles del Siglo de Oro, Barcelona, Crítica, 1983, núm. 43.

${ }^{9}$ Traduzco de Hans-Jörg Uther, The Types of International Folktales. A Classification and Bibliography, Based on the System of Antti Aarne and Stith Thompson, Helsinki, Suomalainen TiedeakatemiaAcademia Scientiarum Fennica, 2004, núm. 757.
} 
han hecho indagaciones -atentas la gran mayoría a sus versiones medievales-acerca de este cuento. Y señala que versiones orales han sido registradas además en Livonia, Letonia, Lituania, Carelia, Islandia, España ${ }^{10}$, Alemania, Hungría, Malta, República Checa, Eslovaquia, Macedonia, Bulgaria, Polonia, Rusia, Bielorrusia, Ucrania, en varias tradiciones judías, entre los kirguises, y en Siria, la India, la República Dominicana y Guinea.

Aunque tampoco se haya tenido hasta ahora en consideración, el cuento ATU 757 (La jactancia del emperador) se halla en estrecha relación, según creo, con el tipo ATU 836 (Pride is Punished), que suele estar protagonizado por un hombre rico -no por un rey o emperador-, y que ha sido registrado en Finlandia, Estonia, Lituania, Suecia, Inglaterra, Irlanda, Alemania, Eslovenia, Serbia, Macedonia, Bulgaria, Polonia, en algunas tradiciones judías, China y Egipto. De hecho, las versiones rusas de Afanásiev que más adelante conoceremos son, en realidad, contaminación de estos dos tipos. He aquí el resumen de ATU 836:

El orgullo castigado. Un hombre rico (o una mujer rica) se jacta (muchas veces durante la misa) para sus adentros (o en una conversación) de que sus riquezas son tan inmensas que ni siquiera Dios podría nunca quitárselas. Cuando vuelve a casa, sus propiedades han quedado completamente destruidas (la casa se ha incendiado) y queda sumido en la pobreza para el resto de sus días ${ }^{11}$.

\section{Las estructuras trimembres del exemplo de Lucanor, el episodio del destierro del Cantar de mio Cid, la leyenda de Lear y el cuento de El amor como la sal}

El tipo cuentístico -es decir, el argumento típico- ATU 757 (La jactancia del emperador) se identifica a la perfección con la materia narrativa del exemplo 51 de don Juan Manuel. Pero yo, en lugar de mantener mi análisis dentro de los márgenes estrictamente argumentales, voy a intentar ampliar el radio de la búsqueda, y a enfrentar nuestro exemplo juanmanuelino a correlatos con los que mantiene analogías narrativas que no son solo argumentales

\footnotetext{
${ }^{10}$ En realidad, no ha sido recogida en la tradición oral moderna española o hispánica ninguna versión, que yo sepa, de nuestro relato. El catálogo ATU se limita a remitir, a través de la antología de Chevalier, a la versión de don Juan Manuel y a dos de los Siglos de Oro (a la versión del Auto del Emperador Juveniano, y a la de Herrera). No hay consignada ninguna versión tradicional en el canónico libro de Julio Camarena Laucirica y Maxime Chevalier, Catálogo tipológico del cuento folklórico español. Cuentos religiosos, Alcalá de Henares, Centro de Estudios Cervantinos, 2003.

${ }^{11}$ Traduzco de Uther, The Types of International Folktales, ob. cit., núm. 836.
} 
o tipológicas, y que hallaremos -lo que hará más difícil pero también más sugerente nuestra indagación- emboscados en otros géneros literarios:

- en la épica (en un episodio del Cantar de mio Cid);

- en la leyenda y el teatro inspirado en la leyenda (el King Lear de las crónicas británicas medievales, de las que manó el drama de Shakespeare);

- y en el cuento tradicional suministrador de tramas de la leyenda: en concreto, en el de Love like Salt (El amor como la sal), que tiene el número 923 en el catálogo $\mathrm{ATU}^{12}$, y está considerado como una de las fuentes tradicionales de la leyenda de Lear.

Para otra ocasión dejaremos la comparación con una magistral novela mucho más moderna (The Prince and the Pauper, o El principe y el mendigo, fechada en 1881, de Mark Twain), que muestra también coincidencias tan específicas como notables con el argumento del relato internacional del que es avatar el cuento de don Juan Manuel.

Adelanto ya que los episodios de las tres obras medievales (más el cuento tradicional) que acabo de poner en relación se acogen a un guión argumental que coincide en unos cuantos hitos muy relevantes, y en el orden en el que se desarrollan: un noble pronuncia unas palabras soberbias (o tenidas por soberbias), a las que responde un superior suyo con palabras de ira, que imponen la exclusión y el destierro del primero. Después, tras una serie más o menos larga y accidentada de peripecias exílicas, el señor superior y el súbdito se reconcilian, y el que había perdido sus dignidades y propiedades las recupera. En todas estas obras (menos en el cuento de El amor como la sal), el sujeto alienado, convertido en un paria, pide a quienes fueron antes sus deudos que le dejen entrar en su casa y que reconozcan su dignidad y autoridad. Pero recibe una serie (por lo general tres) de respuestas negativas.

El exemplo 51 de El conde Lucanor es bastante extenso, y resultará, sin duda, perfectamente familiar a los lectores de este artículo, por lo que no voy a reproducirlo ${ }^{13}$. Está atravesado, por otro lado, de tópicos folclóricos y narrativos de gran enjundia, cuyo análisis exhaustivo precisaría más espacio que el que está ahora a nuestro alcance.

Nos fijaremos, por el momento, solo en las escenas en las que el rey despojado de sus bienes y dignidades, y excluido y ninguneado por sus súbditos

\footnotetext{
${ }^{12}$ Véanse, sobre este cuento, Simona Serra, «El agua y la sal (ATU 923), cuento tradicional siciliano de la colección de G. Pitrè», en Culturas Populares. Revista Electrónica 4 (enero-junio 2007); y José Manuel Pedrosa, «Comer con sal, comer sin sal, o lo civilizado frente a lo salvaje: el cuento ATU 923 (El amor como la sal) y otras fábulas de princesas desterradas y recuperadas», en Culturas Populares. Revista Electrónica 4 (enero-junio 2007).

${ }^{13}$ La versión que yo tomo como referencia es la de Don Juan Manuel, El conde Lucanor, ed. de Guillermo Serés, Barcelona, Crítica, 2001, pp. 219-226.
} 
y paisanos (para que se cumpla así el designio del airado Dios), pide primero (recurriendo incluso a una violencia física que no le sirve para nada) a su portero, luego a su mayordomo y después a su esposa, que lo acojan dentro de su propio palacio, a lo que ellos se niegan de plano. Tengamos en cuenta, además, que en las otras cuatro versiones medievales analizadas por Biaggini, los súbditos que excluyen, desprecian y a veces hasta golpean al rey, reducido a la condición de paria expropiado, son un caballero al que él había antes favorecido, un duque y la emperatriz (en los Gesta Romanorum); su hermano el duque de Baviera y su hermano el rey de Aragón (en Li dis dou magnificat de Condé); un sacristán y un portero (en el anónimo Robert of Cisyle); y unos ribaldos, unos labradores y los guardias de su palacio (en la novella de Sercambi). En el dilatado conjunto de los paralelos del tipo ATU 757 (La jactancia del emperador) que, aparte de esos, se conocen, predominan, igualmente, los que se acogen a series trimembres.

Contrastemos tales escenas con la que desgranan los versos 29-74 del Cantar de mio Cid, aquellos que muestran a Rodrigo despojado, igualmente, de sus bienes y dignidades, y excluido y ninguneado por sus antiguos aliados burgaleses, para que se cumpliera así un decreto dictado por el airado rey Alfonso VI -quien de ese modo le quería castigar, aunque esa escena no aparezca en el Cantar, por lo que consideraba palabra soberbia de su súbdito-. Tras golpear violentamente la puerta de su propia «posada» en Burgos («sacó el pie del estribera, una ferida·l' dava»), Rodrigo escucha de una «niña de nuef año» - porque ningún adulto se atreve a hacerle frente- las razones que alegan quienes fueron sus deudos para no darle hospitalidad. La niña no le responde con acritud ni con insultos, como hacen los personajes del exemplo juanmanuelino, sino con moderación y sensibilidad: «Cid, en el nuestro mal vós non ganades nada, / mas el Criador vos vala con todas sus vertudes santas». El episodio no deja de causar extrañeza, ya que Rodrigo, aunque joven -relativamente: estaba casado y tenía dos hijas- y «pequeño infanzón o hidalgo de aldea ${ }^{14}$, radicado en el vecino pueblo de Vivar (a unos diez kilómetros de Burgos), gozaba ya de una posición carismática en el escenario político castellano, y sería de esperar, por ello, que en la corte de Burgos contara con algo más que una mercenaria «posada» regida por sujetos tan pusilánimes y poco respetuosos como los que le dieron con la puerta en las narices en aquella comprometida ocasión.

Los versos siguientes insisten en que el Cid «posó en la glera cuando no 1 ' coge nadi en casa» y en que «vedada l'an conpra dentro en Burgos

${ }^{14}$ Así es definido en el Cantar de mio Cid, ed. de Alberto Montaner, Madrid, Real Academia Española, 2011, p. IX. 
la casa / de todas cosas cuantas son de vianda». Versos que dan a entender que ningún vecino de Burgos - ni los de su «posada» ni los de otras casas burgalesas en que hubiera querido hacer «conpra»- quiso darle hospitalidad ni venderle vituallas. Desconsideración que se explica mejor si se tiene en cuenta que el Cid, por ser de Vivar, no era allí señor natural, por más que fuera caudillo perfectamente conocido, y hasta de cierto prestigio y carisma.

Cierra la serie trimembre (la que comenzó la niña y continuaron los burgaleses en general) la generosa intervención de Martín Antolínez, el único burgalés que auxilia a Rodrigo y a su mesnada de Vivar, y que le ofrece las viandas que -detalle significativo- guardaba en su casa («abástales de pan e de vino; / non lo conpra, ca él se lo avié consigo»), aunque sabe que el precio que tendrá que pagar por ello será el de la renuncia a aquella casa y el destierro:

Grande duelo avién las yentes cristianas, ascóndense de mio Cid, ca no l'osan dezir nada.

El Campeador adeliñó a su posada, así commo llegó a la puerta, fallóla bien cerrada, por miedo del rey Alfonso que assí la avién parada, que si non la quebrantás por fuerça, que non ge la abriese nadi.

Los de mio Cid a altas vozes llaman, los de dentro non les querién tornar palabra. Aguijó mio Cid, a la puerta se llegava, sacó el pie del estribera, una ferida.l' dava; non se abre la puerta, ca bien era cerrada. Una niña de nuef años a ojo se parava:

- ¡Ya Campeador, en buen ora cinxiestes espada!

El rey lo ha vedado, anoch d'él entró su carta con grant recabdo e fuertemientre sellada. Non vos osariemos abrir nin coger por nada; Si non, perderiemos los averes e las casas, e demás los ojos de las caras.

Cid, en el nuestro mal vós non ganades nada, mas el Criador vos vala con todas sus vertudes santas.Esto la niña dixo e tornós' pora su casa.

Ya lo vee el Cid, que del rey non avié gracia; partiós' de la puerta, por Burgos aguijava, llegó a Santa María, luego descavalga, fincó los inojos, de coraçón rogava. La oración fecha, luego cavalgava, salió por la puerta e Arlançón passava; 
cabo essa villa en la glera posava, fincava la tienda e luego descavalgava.

Mio Cid Ruy Díaz, el que en buen ora cinxo espada, posó en la glera cuando no·l' coge nadi en casa, derredor d'él una buena conpaña; assí posó mio Cid commo si fuesse en montaña. Vedada l'an conpra dentro en Burgos la casa de todas cosas cuantas son de vianda; non le osarién vender al menos dinarada. Martín Antolínez, el burgalés conplido, a mio Cid e a los suyos abástales de pan e de vino; non lo conpra, ca él se lo avié consigo, de todo conducho bien los ovo bastidos. Pagós' mio Cid e todos los otros que van a so cervicio. Fabló Martín Antolínez, odredes lo que á dicho:

- ¡Ya Canpeador, en buen ora fuestes nacido!

Esta noch yagamos e váimosnos al matino, ca acusado seré por lo que vos he servido, en ira del rey Alfonso yo seré metido ${ }^{15}$.

Los últimos versos de esta secuencia (la que comienza «Mio Cid Ruy Díaz, el que en buen ora cinxo espada...») son extraordinariamente significativos para nosotros, porque se acogen a una estructura que es, al fin y al cabo, trimembre (como la del relato juanmanuelino o la del King Lear que enseguida analizaremos): a Rodrigo le niega hospitalidad y auxilio primero la niña que habla por los dueños de su «posada»; luego los demás burgaleses que le niegan la «conpra» de vituallas, los cuales quedan sin identificar por sus nombres y cuyo número es indeterminado; solo Martín Antolínez contradice, al final de esa secuencia de tres, tales desafecciones.

Es relevante el uso que se hace de la voz casa dentro del episodio: «posó en la glera cuando no $\cdot 1$ ' coge nadi en casa»; «vedada l'an conpra dentro en Burgos la casa» (el énfasis puesto sobre las casas que no se le abrieron al Cid es marca mía). También lo es el verso «esta noch yagamos e váimosnos al matino», puesto en boca del abnegado Martín Antolínez, quien no concreta en qué lugar propone a los desterrados yacer aquella noche, si en la glera o en su casa. El texto del Cantar deja claro que el Cid, antes de encontrarse con Martín Antolínez, «en la glera posava, fincava la tienda e luego descavalgava», y el verso 208 concretará más adelante de qué modo fue levantada la tienda al punto de abandonar Burgos: «mandad coger la tienda e vayamos

\footnotetext{
${ }^{15}$ Cantar de mio Cid, vv. 29-74.
} 
privado». Pero el caso es que la tienda del Cid fue utilizada aquella noche para albergar en ella la visita y para consumar el engaño a los prestamistas Rachel y Vidas, y el Cantar no concreta ni dónde durmieron ni si durmieron siquiera el Cid y los suyos aquella ajetreada noche.

Lo que sí sugiere es que de la casa de Martín Antolínez, la única que les dio ayuda, sacarían también -pues es inverosímil que, desterrados, carentes de vituallas y de lo más elemental, hubiesen salido de Vivar con mamotretos tan pesados y aparatosos- las «dos arcas... / cubiertas de guadalmecí e bien enclaveadas, / los guadamecís vermejos e los clavos bien dorados» que servirían para engañar a Rachel y Vidas. El papel protagonista que el burgalés Martín Antolínez desempeña en las dos escenas contiguas -la de la provisión de suministros a los desterrados, y la del engaño a los prestamistas- les señala, a él y a su casa, como providenciales y comprometidos anfitriones burgaleses.

Hallamos confirmación, así, de que nuestro episodio del Cantar de mio Cid se ajusta a una estructura trimembre, y al guion narrativo de las tres casas (o de las tres secuencias que atañen a casas) en las que el señor excluido por una autoridad superior pide acogida. Más velada y menos marcada y formularia que la del exemplo 51 de don Juan Manuel; pero incuestionable.

\section{El rey de la palabra soberbia de don Juan Manuel, el Cid que levanta la voz en Santa Gadea y la Cordelia que da una respuesta sincera a Lear}

No cabe duda de que entre el episodio narrado por don Juan Manuel y el que se halla inserto dentro del Cantar de mio Cid se detectan analogías estructurales más que llamativas. En ambos casos, una autoridad superior y airada (Dios, Alfonso VI) por lo que considera una agresión soberbia de un súbdito contra el orden instituido (aunque la insubordinación se manifieste por la vía puramente verbal) decreta que el tal súbdito (el rey, Rodrigo) sea despojado, en castigo por sus palabras, de sus bienes y dignidades, y que le sea negada la entrada y la manutención dentro de sus propias casas y propiedades, como fase previa a su exclusión y destierro. Hay que insistir -porque será una cuestión también clave en el relato de la ira de Lear contra su hija Cordelia, otra insumisa verbal (no pecadora soberbia) joven, justa y valerosa como Rodrigo- en que las faltas de todos estos súbditos fueron de insubordinación manifestada a través de la palabra; en que sus superiores los consideraron deslealmente soberbios por ello (aunque, desde el punto de vista de la ética del narrador y del receptor, el único soberbio fuera el rey del exemplo 51 de don Juan Manuel, no Rodrigo ni Cordelia); y en que todos esos actos de disidencia verbal fueron realizados en el marco de unos espacios 
significativamente sagrados o solemnes: el rey juanmanuelino (mientras escuchaba un magnificat, posiblemente dentro de una iglesia) había dictado palabras que pretendía que corrigiesen las palabras de Dios, lo que humillaba a este. Rodrigo -en un episodio que no tuvo reflejo en el Cantar de mio Cid, pero sí en leyendas y romances- había pronunciado una exigencia solemne (según algunas tradiciones tardías, dentro de la iglesia de Santa Gadea de Burgos) para obligar a jurar a Alfonso VI que no había sido cómplice en el asesinato de su hermano Sancho II, lo que humillaba igualmente a su señor; el cual, en aquella misma iglesia, respondería con la sentencia de exclusión y destierro. Cordelia había pronunciado una frase («siempre te he amado como se ama a un padre», en la versión de la Historia Regum Britanniae, ca. 1150, de Geoffrey de Monmouth ${ }^{16}$, muy anterior a la tragedia, ca. 1605-1606, de Shakespeare), que Lear interpretó como insuficiente muestra de amor y como proclama de humillante insubordinación filial, en una ceremonia que tuvo lugar en el palacio real, ante lo cual el padre maldijo y desterró, allí mismo, a quien tachó de hija rebelde. En el cuento tradicional ATU 923, El amor como la sal, que tanto tiene que ver con la trama de King Lear, la frase pronunciada por la hija tercera que encoleriza al padre viene a ser de este cariz: «te quiero tanto como se quiere a la sal».

No vendrá mal recordar aquí, puesto que acabamos de referirnos a tal episodio, el romance de La jura de Santa Gadea, tan célebre y tan inventivo - pues es desarrollo de tradiciones cidianas apócrifas y tardías-, que nos muestra a un Cid valiente y deseoso de justicia pero que no deja de incurrir en destemplada soberbia en el momento en que toma juramento a su rey. Aunque este Cid tardío y altisonante no tenga mucho que ver con el Cid primitivo y mesurado del Cantar, muestra de manera muy nítida la potencia letal con que la secuencia (y la suma) de la palabra soberbia y de la palabra airada -realzadas por lo solemne de la ocasión y del escenario-puede desencadenar la ruptura de la alianza política:

En sancta Gadea de Burgos do juran los hijos dalgo, allí le toma la jura el Cid al rey castellano.

Las juras eran tan fuertes, que al buen rey ponen espanto; sobre un cerrojo de hierro y una ballesta de palo:

-Villanos te maten, Alonso, villanos, que no hidalgos, de las Asturias de Oviedo, que no sean castellanos; mátente con aguijadas, no con lanzas ni con dardos;

\footnotetext{
${ }^{16}$ Geoffrey de Monmouth, Historia de los reyes de Britania, trad. Luis Alberto de Cuenca, Madrid, Alianza, 2004, p. 59. El episodio completo de Lear se hallará en las pp. 57-63.
} 
con cuchillos cachicuernos, no con puñales dorados; abarcas traigan calzadas, que no zapatos con lazo; capas traigan aguaderas, no de contray, ni frisado; con camisones de estopa, no de holanda, ni labrados; caballeros vengan en burras, que no en mulas ni en caballos; frenos traigan de cordel, que no cueros fogueados. Mátente por las aradas, que no en villas ni en poblado, sáquente el corazón por el siniestro costado, si no dijeres la verdad de lo que te fuere preguntado: si fuiste, ni consentiste en la muerte de tu hermano. Jurado había el rey, que en tal nunca se ha hallado; pero allí hablara el rey malamente y enojado:

-Muy mal me conjuras, Cid, Cid, muy mal me has conjurado; mas hoy me tomas la jura, mañana me besarás la mano.

- Por besar mano de rey no me tengo por honrado; porque la besó mi padre me tengo por afrentado. -Vete de mis tierras, Cid, mal caballero probado, y no vengas más a ellas dende este día en un año.

-Pláceme, -dijo el buen Cid-, pláceme, -dijo-, de grado, por ser la primera cosa, que mandas en tu reinado.

Tú me destierras por uno, yo me destierro por cuatro.

Ya se parte el buen Cid, sin al rey besar la mano, con trescientos caballeros, todos eran hijos dalgo; todos son hombres mancebos, ninguno no había cano. Todos llevan lanza en puño y el hierro aciclado, y llevan sendas adargas, con borlas de colorado; mas no le faltó al buen Cid adonde asentar su campo ${ }^{17}$.

No tenemos espacio, aquí, para desgranar y analizar episodios sin duda cruciales de los extensos y complejos King Lear de Monmouth y Shakespeare. Como se trata, en cualquier caso, de obras bien conocidas, nos conformaremos con señalar que el drama tardío de Shakespeare es mucho más inventivo y proclive a la palabra altisonante y patética que el relato viejo de Monmouth. Resulta llamativo, por ejemplo, que, en la versión de Monmouth, Lear llamase «por separado para saber cuál de las tres lo amaba más» ${ }^{18}$ a cada una de sus hijas. En el de Shakespeare, las tres hijas comparecen juntas, ante la nobleza, y entre aparatosos sones de trompas. El contraste entre la

${ }^{17}$ Romance que fue publicado en el Cancionero de romances s.a, en el Cancionero de romances de 1550, en la Silva de 1550, en Timoneda, Rosa española; reeditado en Fernando José Wolf y Conrado Hofmann, Primavera y flor de romances o colección de los más viejos y más populares romances castellanos, Berlín, A. Asher \& Co., 1856, núm. 52, vol. I, pp. 158-161.

${ }^{18}$ Monmouth, Historia de los reyes de Britania, p. 58. 
privacidad y la falta de espectacularidad de la versión primitiva de Monmouth y la solemnidad palaciega de la versión tardía de Shakespeare corren, en cierta medida, en paralelo con lo que se detecta en el dilatado ciclo narrativo del Cid, en el que las exageraciones patéticas -el caso hiperbólico de la apócrifa jura de Santa Gadea es paradigmático- van ganando terreno a medida que pasan los siglos y la leyenda se aleja de sus referentes históricos ${ }^{19}$.

Convendrá tener también presente, puesto que nos estamos refiriendo insistentemente a él, el resumen que del cuento ATU 923 (Love like Salt), tan pluricultural (ha sido documentado en tradiciones que van desde Finlandia hasta China, o desde México hasta Sudáfrica), y tan relacionado con el ciclo narrativo de King Lear, ofrece el catálogo ATU:

El amor como la sal: un rey (o un hombre rico) pregunta a sus tres hijas cuánto le aman. Las dos mayores comparan su amor con cosas muy preciosas (o dulces), como el oro, las piedras preciosas, el azúcar, la miel, los vestidos más valiosos. Pero la menor dice que ella le ama igual que a la sal. El padre se siente ofendido por la respuesta de la hija más joven, y la destierra (o bien decreta su muerte), mientras que recompensa a las hijas mayores de modo proporcional al valor de sus aseveraciones.

La hija más joven se pone a trabajar entonces como sirvienta en un país lejano, con cuyo rey acaba casándose. Ella invita a su padre al banquete de bodas, y le sirve platos que no tienen sal. De ese modo el padre se da cuenta de que la sal es indispensable. La hija entonces revela su identidad ${ }^{20}$.

${ }^{19}$ Sobre la evolución, cada vez más fantasiosa y exagerada, del tópico del enfrentamiento verbal entre Alfonso VI y Rodrigo, véase José Manuel Pedrosa, «Crimen real, ira regia, exclusión del héroe justo: el Cid, Jasón, Aquiles, Hamlet, Cordelia», en Sonando van sus nuevas allent parte del mar: el Cantar de mio Cid y el mundo de la épica, coord. de Alberto Montaner Frutos, Toulouse, CNRS-Université de Toulouse-Le Mirail, 2013, pp. 297-328, pp. 299-300: «De hecho, las crónicas latinas más viejas, el Chronicon Mundi (ca. 1236) de Lucas de Tuy y el De Rebus Hispaniae (ca. 1243) de Rodrigo Ximénez de Rada, se limitaban a describir la exaltación de Alfonso como rey de los leoneses, gallegos y asturianos en Zamora y a añadir que el grupo de los castellanos pidió, también en Zamora y por boca de Rodrigo, que jurase que no había sido cómplice en la muerte de su hermano don Sancho, lo cual no encontró nada «graciosus» el rey. Hay que esperar unas cuantas décadas, hasta las crónicas en lengua vulgar (la Estoria de España alfonsí y sus distintas versiones, ramas y epígonos) para que encontremos el traslado del episodio de la Jura a la ciudad de Burgos y a la iglesia de Santa Gadea y para que veamos a Rodrigo asumiendo un papel de censor activo y singular del rey, a quien primero se niega a besar las manos (mientras que el resto de los castellanos lo había hecho ya), luego espeta sin ningún tapujo que hay "sospecha que por vuestro consejo fue muerto el rey don Sancho" y toma después el juramento. El rey queda, obviamente, profundamente incómodo y resentido, pero en ninguna de estas versiones cronísticas dependientes del modelo alfonsí se produce el estallido de ira regia ni la inmediata condena de destierro que fundirán con esa escena los romances del xvi: muestran más bien a un Alfonso que, tras superar la dura prueba, queda silencioso, incubando y tramando una respuesta que vendría después».

${ }^{20}$ Traduzco de Uther, The Types of International Folktales, ob. cit., núm. 923. 
Pero volvamos a la comparación entre nuestros textos: tras los pronunciamientos del rey juanmanuelino, de Rodrigo, de Cordelia y de la princesa que gustaba de la sal, tenidos por desafíos inaceptablemente soberbios por sus superiores (Dios, Alfonso VI, Lear, el rey del cuento ATU 923), y tras las subsiguientes y airadas sentencias de expropiación y de destierro, la fuerza de la palabra de los nobles que osaron desafiar a sus superiores pierde efectividad: ninguno podrá, mediante el uso de la voz (e incluso de amagos insuficientes o inoperantes de violencia física), persuadir a quienes toman el control de sus casas para que les sea permitido volver a entrar en ellas. Todos estos relatos se nos muestran, así, como intensos torneos verbales, en los que la palabra soberbia (o tenida por soberbia) antecede y se contrapone siempre a la palabra airada, y en que la sucesión automática (y la suma) de ambas se convierte en detonante de una situación de ruptura de la alianza familiar y política que pone en crisis todo el sistema social y cultural. Hasta que, al cabo de muchas peripecias, sean pronunciadas las palabras -siempre las palabras- de perdón y reconciliación que rediman a todos y salven cada uno de esos mundos del caos lingüístico y político en que se habían precipitado.

En el exemplo 51 de El conde Lucanor, todas las porfías del señor alienado no logran que su portero, su mayordomo o su esposa (los sujetos que conforman la serie trimembre) tengan piedad de él y lo acojan, y por ello se ve obligado a seguir su fatal camino hacia el destierro. En el Cantar de mio Cid, la violenta patada en la puerta de su propia "posada» y las palabras conminatorias de Rodrigo no sirven tampoco para nada, y no logran que sus antiguos amigos burgaleses le acojan, aunque al menos obtiene las buenas palabras de la «niña de nuef años»; tras lo cual solo queda marchar al exilio, pues tampoco la hospitalidad y la ayuda ofrecidas por Martín Antolínez (quien completa la serie trimembre que articula el episodio) podía ser operativa en aquel Burgos clausurado legalmente para él. En el complejo narrativo protagonizado por Lear, el primero soberbio y después fragilísimo rey se ve condenado a implorar los favores y la hospitalidad de las dos hijas a las que había favorecido (y que acaban arrojándolo de sus propiedades y desposeyéndolo de todo), y solo encuentra acogida digna en la casa de la hija (la tercera de la serie) a la que antes había maldecido y desterrado. En el cuento tradicional ATU 923, El amor como la sal, el rey soberbio que había desterrado a su hija tercera (la que vuelve a completar la serie trimembre) se convierte, pasado el tiempo, en huésped ( $\sin$ saberlo) de ella, quien le demostrará, cuando le presente una comida intolerablemente sosa, que las palabras que había pronunciado de que le quería tanto como a la sal eran más sinceras y honestas que las que habían pronunciado sus dos cínicas hermanas. 
Resulta notabilísimo, en fin, que los cuatro relatos terminen con la deposición de la ira, la reconciliación de las partes enfrentadas, la renovación de la alianza política y social. Aunque cada una a su modo: en el relato juanmanuelino, Dios perdona y restituye al rey soberbio cuando considera que el castigo ha sido ya suficiente; en fases más avanzadas del Cantar de mio Cid, Alfonso VI acabará reconciliándose con Rodrigo, gracias en buena medida a los dones que este le envía servicialmente desde su exilio; en el King Lear de Monmouth, el viejo rey es repuesto en su trono (en el que se mantendrá dos años más, hasta su muerte) por su yerno Aganipo, rey de los francos (que se había casado con Cordelia), tras vencer a las huestes de las hijas renegadas, Goneril y Regan, y de sus respectivos esposos. En el King Lear de Shakespeare, el viejo rey depuesto y vindicado por la hija a la que él mismo había airadamente desterrado, apenas podrá gozar, loco y agonizante, de las mieles de un triunfo militar y de una reconciliación que no logran iluminar las sombras de la tragedia en las que Shakespeare lo precipita todo. En el cuento ATU 923, El amor como la sal, el rey acaba igualmente haciendo las paces, in extremis, con la hija a la que había maldecido y desterrado.

No son, todas estas, las únicas analogías que nos van a ir saliendo al paso, pero sí son suficientes para que pueda ir cuajando en nosotros la certeza de que operamos sobre materias narrativas en alguna medida comunes, en no pocos puntos cruzadas.

Aunque tampoco se pueden minimizar las discrepancias que abren fallas y distancias entre ellas. La más sustancial es, sin duda, la que tiene que ver con el punto de vista y con la valoración moral que los narradores y receptores hacen de los personajes de cada relato: el rey de exemplo 51 de El conde Lucanor es, como ya hemos adelantado, un pecador irreverentemente soberbio; mientras que el Rodrigo primitivo (más que el de la tardía Jura de Santa Gadea), Cordelia y la tercera hija del rey del cuento de El amor como la sal no son soberbios, sino templados, honestos, justos y valerosos, a despecho de que los reyes proclives a la ira que tienen poder sobre ellos los condenen por soberbios ${ }^{21}$.

\footnotetext{
${ }^{21}$ Acerca del concepto de pecado, tan relevante en los textos que estamos analizando (en el exemplo 51 de El conde Lucanor palabras de la familia léxica de pecar aparecen hasta diecinueve veces), y de sus representaciones literarias, especialmente en los textos medievales, estoy desarrollando una serie de artículos que, por el momento, han atendido ya a los pecados de la avaricia, la ira, la pereza y la soberbia: véanse José Manuel Pedrosa, «¿Existe el hipercuento?: Chaucer, una leyenda andaluza y la historia de El tesoro fatal (AT 763)», en Revista de Poética Medieval, 2 (1998) pp. 195-223; Pedrosa, «El cuento de El tesoro soñado (AT 1645) y el complejo leyendístico de El becerro de oro», en Estudos de Literatura Oral, 4 (1998), pp. 127-157; Pedrosa, «Más reescrituras del cuento de El tesoro fatal (AT 763): del Orto do Esposo, Vicente Ferrer y Hans Sachs a Eça de Queiroz, William Faulkner y Max Aub», en Revista de Poética Medieval, 5 (2000) pp. 27-43; Pedrosa, «Crimen real, ira regia»; Pedrosa, en colaboración con
} 
Esa discrepancia en la posición y en la valoración ética resulta fundamental, y suscita o justifica, de algún modo, otras fallas que se detectan entre nuestros relatos, sobre todo entre el de El conde Lucanor y todos los demás. La más llamativa puede que sea que, en el relato de don Juan Manuel, el rey no es reconocido por sus súbditos como tal, sino que es confundido con un mendigo loco, mientras un ángel actúa como su sustituto; mientras que el Rodrigo del Cantar de mio Cid no se ve enajenado de su identidad, por más que los burgaleses se vean obligados a negarle el tratamiento de señor y amigo; y en el denso y variable elenco de obras protagonizadas por Lear, el rey es también perfectamente identificado por sus antiguos deudos, aunque lo traten como a un indigno pordiosero, y en algunas versiones (la de Shakespeare, por ejemplo) como a un pobre loco. Tampoco el rey del cuento de El amor como la sal pierde nunca su identidad: quien sí la pierde, llamativamente, es la hija a la que él envió al destierro y que, al cabo de unas cuantas peripecias y disfraces, se reencuentra con su padre (y le sirve un manjar insoportablemente soso), sin que él pueda identificar a su hija hasta el momento en que ella se da a conocer.

Hay otra discrepancia que creo que merece la pena destacar, sobre todo para que podamos hacer mejor justicia a esa obra de insólita calidad y originalidad literarias que es el Cantar de mio Cid. Nuestro episodio épico se nos revela como una obra mucho más matizada, atenta al claroscuro psicológico, a la pintura realista, que el esquemático, maniqueo e inverosímil exemplo 51 de El conde Lucanor, con su impostado ingrediente milagroso (el ángel sustituto) y su rutinario y previsible formulismo trimembre (los tres súbditos que rechazan, como siguiendo un guion mecánico, a su señor). Los relatos acerca del rey Lear (en especial el hondísimo de Shakespeare, claro), y el cuento tradicional ATU 923 (El amor como la sal), aunque sometidos también a la previsible y formulaica regla de tres (en su caso, de las tres hijas), se hallan más cerca del Cantar de mio Cid que del acartonado exemplo juanmanuelino, en lo que se refiere al margen de acción, a la pintura psicológica y a la credibilidad realista de los personajes. De hecho, el que la tercera hija del rey se comporte de manera netamente diferente de como hacen sus dos hermanas introduce en estos relatos una asimetría que se separa algo de la monocorde uniformidad del relato juanmanuelino.

\footnotetext{
Awa Traoré, «Los dos perezosos (ATU 1950) de Juan Ruiz y la tradición oral diula de Costa de Marfil: traducción, transmisión, tradición», E-Humanista, 28 (2014) pp. 643-699; y Pedrosa, «Odiseo, Gengi, el Cid y Gorba Dikko: soberbia épica, violencia verbal y frontera acuática», en Atalaya, número monográfico coordinado por Alberto Montaner, en prensa.
} 
Pero el episodio del Cantar de mio Cid es mucho más libre, suelto, ajeno a guiones acuñados, que cualquiera de los otros. Aunque sometido también a la regla de tres, cada sujeto interpelado responde de manera muy distinta al Cid interpelante: la niña, con temor y compasión; los burgaleses que no le abren sus casas, con miedo e indignidad; Martín Antolínez, con valentía y abnegación. Nuestra vieja escena épica se nos muestra, pues, como una trama más rica, más dúctil, más polifónica, más naturalista, en cierto sentido más moderna, que cualquiera de sus correlatos.

Aunque cada lector y cada crítico tenga el derecho de acogerse a su propia opción hermenéutica $-\mathrm{y}$ muchos críticos defienden con absoluta determinación que el Cantar de mio Cid es hijo de alguna sofisticada escritura clerical o cortesana, y no de la más libre y agreste voz oral juglaresca-, a mí me parece que el relato de El conde Lucanor responde a un tipo de discurso institucional, esquemático, formulario, sermonario, abstractamente idealista, que ha sido evidentemente delineado en un escritorio de corte o de monasterio. Y también que el episodio del Cantar de mio Cid, tan lleno, en cambio, de aliento humano y tan despojado de ampulosidad, tan atravesado de ansiedad e incertidumbre, fruto de lo que parece ser un arte poético natural (o naturalista), sincero, no impostado, no tiene trazas de ser fruto del tiralíneas ideologizado de ningún scriptorium, sino de algún poeta -algún juglar que con su voz apelase directa y patéticamente al oído de su auditorio-que habría elaborado sus versos bastante al margen de los registros y convenciones políticos, religiosos y literarios (retóricos y estéticos) instituidos.

Sea como sea, no se trata solo de que los puntos de vista sean radicalmente distintos: el del -en mi opinión- juglaresco, oral, popular Cantar de mio Cid, y el de Lear y El amor como la sal-nacidos todos, en última instancia, del folclore-, ensalzan al héroe disidente, al sujeto subordinado que alza su voz contra el poder; mientras que el exemplo -nacido en la corte, a la sombra de la iglesia- del aristocrático don Juan Manuel condena y aplasta al sujeto rebelde a la autoridad, a quien se atreve a levantar la voz contra el discurso de las instituciones religiosas o políticas. Se trata, más allá de esa diferencia, de que la escena desolada, honda, desnuda, del Cantar de mio Cid va mucho más allá que cualquiera de los otros relatos en cuanto al diseño de unos personajes que parecen de carne y hueso, a la propuesta de soluciones narrativas no acuñadas ni previsibles, al distanciamiento de los clichés de la literatura para acercarse a la variedad imprevisible de la vida. Rodrigo no fue solo un insumiso a la autoridad de su rey; fue un rebelde, también, a las normas retóricas y estéticas de la literatura de escritorio. 


\section{Las dos versiones rusas de Afanásiev}

Los paralelos del exemplo 51 de El conde Lucanor que Olivier Biaggini analizaba en detalle en su crucial monografía -que ha sido nuestro punto de partida-, se hallaban insertos -recordémoslo- en los Gesta Romanorum latinos, el francés Li dis dou magnificat de Condé, el anónimo inglés Robert of Cisyle, y una colección de novelle italianas de Sercambi. Ejemplos todos de la tradición más típicamente medieval y más occidental de nuestro tipo cuentístico. Por eso será tan aleccionador asomarnos ahora a dos versiones rusas que fueron publicadas en las Russkie narodnye legendy (Leyendas populares rusas, 1859) de Alexandr Nikoláievich Afanásiev ${ }^{22}$. Dos versiones que tienen el interés adicional de que la primera está sacada, según indicación de Afanásiev, de un «viejo manuscrito», mientras que la segunda refleja, en cambio, la tradición oral del «pueblo» ruso de mediados del siglo XIX; es decir, que nos desvelan dos estratos poéticos y cronológicos diferentes, y una muy sugestiva cantidad y calidad de variantes con respecto a las versiones occidentales más cercanas y conocidas para nosotros.

No contamos, por desgracia, con espacio suficiente para analizar en detalle estas dos opulentas versiones rusas. Pero no quiero dejar de señalar que ambas son -se apreciará más intensamente en la segunda, que está protagonizada por un hombre rico, no por un rey- contaminación de los tipos ATU 757 (La jactancia del emperador) y ATU 836 (El orgullo castigado), que es un tipo que suele estar articulado -recordemos-en torno a un rico prepotente. Apreciemos también que los motivos de la cacería en la que participa el rey, el ciervo que causa su extravío, el río que es frontera con el más allá, o el viento y el trueno funestos, tienen viejísima e internacional andadura folclórica; y que el final trágico de la segunda versión -tan impregnada de pinceladas y excursos folclóricos-, con la muerte y condenación del rey soberbio al que Dios niega el perdón, es de brutalidad y originalidad absolutamente excepcionales.

La primera de las versiones rusas llevaba esta anotación de Afanásiev: «de la colección de V. I. Dal [gran lexicógrafo y folclorista ruso], a quien esta leyenda, tomada de un viejo manuscrito, fue traída del distrito Shenkúrskiy, en la provincia de Arjánguelsk»:

${ }^{22}$ Alexandr Nikoláievich Afanásiev, Leyendas populares rusas, traducción de Eugenia Bulatova, Elisa de Beaumont Alcalde y Liudmila Rabdanó, edición de José Manuel Pedrosa, Madrid, Páginas de Espuma, 2007, núms. 24:1 y 24:2. 
Leyenda del zar Agguey y de cómo sufrió por su orgullo

Érase, en la villa de Filuyán, un zar. Se llamaba Agguey, y gozaba de gran fama. Un buen día, mientras asistía a la liturgia en una iglesia, escuchaba al diácono leer el evangelio. Y, tras la lectura de varios episodios del evangelio, comprobó que estaba escrito en ellos: «¡Los ricos se empobrecerán, y los pobres se tornarán ricos!». Cuando escuchó aquellas palabras, el zar montó en cólera y dijo:

_ ¡Esas palabras de las escrituras son falsas! Aunque sean del Evangelio, no dicen la verdad.

Y continuó diciendo:

-Yo soy rico y disfruto de gloria. ¿Cómo es posible que me pueda tornar pobre? ¿Y cómo es posible que un pobre pueda hacerse más rico que yo?

Se sintieron invadidos de temor todos los presentes. El zar ordenó meter al diácono en el calabozo y arrancar aquella hoja del evangelio. Luego marchó a su casa y empezó a beber, y a comer, y a llenarse de la alegría de los festejos.

Tras contemplar un ciervo en el campo, salió de caza llevando consigo a unos cuantos mozos. Galoparon persiguiendo al ciervo, que era tan hermoso que el zar les dijo a sus mozos:

- Quedaos aquí. Voy a capturar al ciervo yo solo.

Y volvió a la persecución. El ciervo se lanzó al río y nadó hasta la otra orilla. El zar ató su caballo a un roble, se quitó los vestidos y la ropa, y nadó desnudo hasta el otro lado del río. Cuando cruzó el río, ya no vio al ciervo por ninguna parte.

El ángel de Dios, tras asumir la imagen de Agguey, montó sobre el caballo del zar y dijo a sus mozos:

—El ciervo se ha perdido más allá del río.

Y se dirigió a su villa, en la que se encontraba su zarina.

Mientras tanto, el zar Agguey volvió al lugar en el que había dejado su caballo, y no encontró ni su cabalgadura ni la ropa. Quedó desnudo y absorto en sus pensamientos.

Al final, se dirigió a su villa y, al ver a unos pastores custodiando bueyes, les preguntó:

-Hermanos pequeños, pastores, ¿habéis visto mi caballo y mis vestidos?

Los pastores le preguntaron a su vez:

— ¿Y quién eres tú?

Y les contestó:

- Soy vuestro zar Agguey.

Los pastores le gritaron:

— ¡Desvergonzado! ¿Cómo te atreves a llamarte zar? Si acabamos de ver al zar Agguey camino de su villa, con sus cinco mozos. 
Se pusieron a lanzarle injurias y a darle latigazos y palos. El zar se echó a llorar y a sollozar. Los pastores lo hicieron huir a palos y, desnudo, tomó el camino de su villa. Pronto lo encontraron unos mercaderes de aquella villa y le preguntaron:

—Dinos, buen hombre, ¿por qué estás desnudo?

Les contestó:

-Unos ladrones me han robado la ropa.

Entonces le dieron algo de ropa, vieja y rota. La tomó dando las gracias humildemente, y siguió caminando en dirección a su villa.

Cuando entró en la villa, pidió a una viuda que le diera posada, y empezó a preguntarle:

—Dime, señora mía, ¿quién es vuestro zar?

Y esta le respondió:

— ¿No eres de aquí? Nuestro zar es Agguey.

Siguió haciéndole preguntas:

— ¿Desde hace cuántos años es el zar?

Y ella le contestó:

—Desde hace treinta y cinco años.

Entonces escribió con su propia mano una carta a la zarina, dándole cuenta de cosas y de pensamientos secretos que habían tenido en común. Y encargó a una mujer que llevara la carta a la zarina.

La zarina cogió la carta y ordenó que se la leyeran. Lo que allí había escrito es que él era su marido, el zar Agguey. Un miedo tremendo se apoderó de ella, y empezó a hablar asustada:

- ¿Cómo puede ser que ese hombre tan humilde me llame su esposa? Si de ello se entera el zar, me manda ajusticiar.

Ordenó que le dieran crueles latigazos, sin decirle nada al zar. Lo golpearon sin piedad, y le dejaron irse más muerto que vivo. Se marchó de la villa llorando y sollozando, acordándose de las palabras que decía el Evangelio acerca de los ricos que caerían en la miseria y de los pobres que se tornarían ricos.

Arrepentido, confesó al cura que había injuriado al Santo Evangelio y que había metido al diácono al calabozo, y a continuación se marchó sin saber adónde.

La zarina dijo al ángel que tenía la apariencia del zar:

- Mi soberano amado, no te acuestas conmigo desde hace un año, ni compartes mi cama. ¿Cómo debo vivir así a tu lado?

El zar le contestó:

- He hecho una promesa a Dios de no acostarme ni compartir la cama contigo durante tres años.

Y se marchó a su aposento.

El zar Agguey llegó a una ciudad desconocida y fue contratado para trabajar durante el verano al servicio de un labrador. Pero como no sabía hacer las 
labores campesinas, el labrador lo despidió. Se echó a llorar y a sollozar, y se marchó de aquella ciudad. Se encontró con unos mendigos y les dijo:

-Llevadme con vosotros, hermanos. Soy pobre e inútil, no sé trabajar, y no me atrevo a pedir limosna, porque me da vergüenza. Estoy dispuesto a hacer lo que me mandéis.

Lo llevaron consigo y le entregaron la bolsa para limosnas que tenía que cargar. Entraron en una posada en la que pasar la noche, y le dieron orden de que caldease el baño, trajese agua y les hiciera la cama a todos. El zar Agguey se echó a llorar amargamente:

— ¡Ay de mí! ¡En qué desgracia he caído! Enojé al Señor. Solo yo tengo la culpa de haber perdido mi reino y de haberme perdido a mí mismo. ¡Todo lo que estoy sufriendo es por las palabras del Evangelio!

A la mañana siguiente se levantaron los mendigos y se dirigieron a su villa de Filuyán. Y, al entrar en el palacio del zar, se pusieron a pedir limosna. En aquel momento, el zar estaba ofreciendo un gran banquete, y ordenó que llevasen a los mendigos al salón y que les sirviesen una buena comida.

También ordenó que condujesen al portador de la bolsa hasta los aposentos del zar, y que lo introdujesen en una habitación reservada.

Cuando la fiesta acabó, y los boyardos y los demás invitados se marcharon, el ángel que tenía la apariencia del zar Agguey se dirigió al aposento en el que comían el zar Agguey y los mendigos.

_ ¿Conoces al zar grande y orgulloso que injurió la palabra del evangelio?

Y se puso a reprenderlo y a enseñarle a no injuriar jamás la palabra del Evangelio, a respetar a los sacerdotes, a no ponerse a sí mismo por encima de los demás, a ser benévolo y humilde ${ }^{23}$.

La segunda versión rusa de Afanásiev llevaba este subrayado: «el cuento del zar Agguey se encuentra en distintas colecciones de manuscritos de los siglos XVII y XVIII. Hay una versión muy similar en la Leyenda sobre el orgulloso César Evinián, que pertenece a la versión rusa de Los hechos de los romanos [los Gesta romanorum]. El pueblo lo cuenta de la manera siguiente»:

\section{El rico orgulloso}

No se sabe en qué parte del mundo vivía un señor tan rico que medía el papel moneda por cajas, el oro por chetveriks ${ }^{24}$, y tenía tantas monedas de cobre

\footnotetext{
${ }^{23}$ Variante: «En otra copia, el ángel preguntó al zar Agguey: — ¿Es verdad lo que dicen en la iglesia de que los ricos se empobrecerán y pasarán hambre? El zar contestó: - Esos versos dicen la verdad. Voy a dar la orden de que lo canten en cada oficio, solo para que el Señor me perdone. El ángel le devolvió sus ricos vestidos y desapareció. El zar Agguey volvió a subir al trono, contó lo que le había sucedido, y ordenó que cantaran en cada oficio los versos de que los ricos se convertirían en pobres y pasarían hambre».

${ }^{24}$ Chetverik, «cuarta, medida para pesar productos en grano o en polvo».
} 
que no era capaz ni de contarlas. ¿Que cuántos siervos, cuántas tierras, cuántos bosques y cuantos prados de siega poseía? Ni me lo preguntes, porque no se podría contar todo.

¡Ay, señor! ¡Pero qué mala suerte tuvo! De ser muy rico pasó a convertirse en más pobre que dos otros pobres pecadores. ¿Y por culpa de qué? Porque se olvidó de Dios, y lo que hacía era sólo para el espíritu del mal.

Mientras la gente buena asistía a la misa del alba en la santa iglesia, en su casa tronaba la música y se bailaba practicando locas prisiadkas ${ }^{25}$. Nunca iba a la iglesia ni sabía para qué lo hacía la gente. Una vez se le antojó ver qué pasaba allí, y el día del Señor fue con su esposa a la misa.

Todos los creyentes estaban rezando. Solamente ellos dos miraban a un lado y a otro, riéndose a carcajadas. No bien leyó el diácono: «Los ricos se tornarán pobres y pasarán hambre», se acercó el señor de un salto, arrancó de sus manos el libro y dio al diácono un golpe en la calva:

-Necio, ¿cómo te atreves a pronunciar tales palabras en mi presencia? ¿Acaso es posible que me torne yo pobre y que pase hambre? ¡Mira que eres canalla! Espera y verás lo qué es reírte de mí. Si tienes el atrevimiento de volver a pronunciar palabras semejantes una vez más, te daré tal cantidad de azotes en el establo que no lo olvidarás hasta que vuelvan a cubrirse de hojas nuevas los árboles. ¡Tráeme el tintero!

El diácono, más muerto que vivo, corrió a buscar un tintero y una pluma, y el pope se escondió en el altar temblando como si tuviera fiebre, el pobrecito. El diácono trajo el tintero y la pluma.

-Mira, necio - dijo el señor-, lo que tacho aquí nunca lo leas, ni mientras yo esté vivo ni cuando me muera.

De repente se levantó un huracán, empezó a relampaguear a cada instante y a tronar más y más fuerte, y luego se produjo un golpe tan fuerte, ¡Dios me guarde!, que todos los que estaban en la iglesia cayeron por tierra. Solamente el señor con su esposa quedaron en pie, reventando de risa.

Vino corriendo el alcalde:

— ¡Ay, qué desgracia! ¡La casa de los señores está ardiendo!

Trataron de apagar el incendio, pero nada pudieron contra la voluntad de Dios. Todo se quemó: sólo quedaron cenizas, como si nunca hubiera habido ninguna hacienda del señor en aquel sitio.

Al rico no le importó aquello lo más mínimo: surgió de allí una mansión aún mejor que la anterior.

Pero, a partir de aquel momento, cada vez que el diácono leía en la iglesia el Evangelio, en cuanto llegaba al párrafo en el que estaba escrito que los ricos se tornarían pobres y pasarían hambre, empezaba a tronar desde el cielo despejado.

${ }^{25}$ Prisiadka, «paso en cuclillas del baile ruso». 
Un día sintió el señor deseos de cazar. Fue reunida mucha gente, unas doscientas personas, y otros tantos perros. Montaron todos sobre sus caballos, tocaron los cuernos y galoparon bosque adentro. La caza fue de liebres y de zorras, de lobos y de osos. De pronto, vieron correr un ciervo tan hermoso que no podían apartar los ojos de él. El señor se puso a perseguir al ciervo: marchó volando tras él, a lomos del caballo, pero el animal era más veloz ${ }^{26}$.

Ya está cerca, ya está a punto de alcanzarlo... ¡Pero no puede!

Pasó el mediodía. Empezó a ponerse el sol. Luego empezó a anochecer, y el señor continuaba tras el hermoso animal. Se hizo de noche, el bosque se quedó más oscuro que la boca del lobo: no se veía nada. Sólo entonces detuvo el señor su caballo. ¿Qué podía hacer? Tocó el cuerno por si lo oían los cazadores. Aguzó el oído. No oía nada: sólo hacía ruido el espeso bosque.

Tocó el cuerno una segunda y una tercera vez. Nadie le contestó. Tan sólo una arboleda lejana repitió: ¡Tururú-tururú! Volvió a salir al galope. Le pareció sentir un poblado cerca, relinchar de caballos y ladrar de perros. Pero seguía sin ver ninguna casucha; tan sólo el cielo y la tierra, y el susurro de las copas de los frondosos pinos alrededor.

Ya estaba tan cansado su caballo que apenas si podía mover las patas, y él mismo ya casi no tenía fuerzas para mantenerse sobre su lomo. De repente, brilló una lucecita. El señor volvió a tocar el cuerno, para que lo saliera a recibir la gente, si había alguna. Consiguió lo que más anhelaba. Unas doce personas salieron de un salto de su escondite detrás de los árboles, y le dispensaron una gran acogida: uno le regaló un golpe tan fuerte en la nuca que el señor cayó a plomo sobre el suelo.

Cuando recobró el sentido, se dio cuenta de que estaba en cueros vivos, igual que cuando vino al mundo. Quiso darse la vuelta iy no pudo! Sus manos estaban atadas a la espalda con una soga. Miró alrededor y vio una hoguera rodeada de bandoleros. Entre ellos estaba el cabecilla, vestido con un caftán rojo. El cabecilla gritó a sus bravos mozos:

- Canallas, ¿por qué no queréis abrigar al señor?

Enseguida una docena de mozos se acercaron corriendo y empezaron a agasajarlo a base de porrazos.

- ¡Basta! -volvió a bramar el cabecilla-. Llevadlo al valle de los lobos y atadlo allí a un árbol. Ya no lo necesitamos para nada, pero aún les servirá a los lobos. ¡Buen bocado va a ser para su desayuno!

Agarraron al señor por los pies, lo llevaron al valle de lobos y lo dejaron fuertemente sujeto a un pino por medio de una soga. Se mantuvo de pie un día y otro día. Ya no podía aguantar más. Sentía las entrañas ardiendo, la boca reseca, su alma a punto de despedirse del cuerpo. ¡Y ni pasaba por su imaginación

\footnotetext{
${ }^{26}$ Variante: «El señor lanzó una flecha, ¡falló!, lanzó otra, ¡otro error!, lanzó la tercera, ¡y tampoco acertó! Echó detrás del animal, fue galopando veloz...».
} 
el arrepentimiento! Sólo pensaba en una cosa: «En cuanto vuelva a mi casa, reúno a los campesinos y ¡a estrangular a esos malditos del bosque!».

No lejos del valle de los lobos pacía ganado. Al mediodía empezó a hacer calor, y los pastores arrearon sus vacas y sus ovejas hacia el valle, para sentarse debajo de los pinos y tejer lápots ${ }^{27}$ a su sombra. ¡Qué sorpresa se llevaron al encontrar a un hombre desnudo que estaba de pie, atados los brazos y las piernas al pino!

- ¡Mira, Gritzkó! - dijo un pastor-. ¡Un hombre en cueros vivos, todo aporreado, todo cubierto de sangre! Vamos a desatarlo, a ver si aún está vivo.

-Pues, vamos - dijo el otro.

Mientras decían tales palabras se acercaron al pino y desataron las sogas. El señor, que había callado antes, gritó en cuanto le quitaron las sogas:

— ¡Ea, mozo! ¡Quítate tu abrigo de sayal y tráemelo! Aunque tu ropaje es malo, es mejor que estar sin nada encima. Y llévame a la casa del señor. Enteraos, canallas, de quién está delante de vosotros: ¡Soy vuestro señor!

— ¡Toma! Ya ves, Gritzkó, qué clase de pájaro es. ¡Nuestro señor! ¡Ja, ja, ja! ¡Te pareces mucho, no hay duda! ¡Vistes un caftán tan rico, todo engalanado! Qué va, hombre, Dios sabrá quién eres tú. Te informo de que nuestro señor está en el palacio, vestido con ropajes de oro.

— ¿Cómo te atreves, bastardo, a decir semejantes groserías a tu señor? Ya te daré yo a ti... Espera a que llegue a mi casa.

El señor, enfurecido, se echó encima del pastor para quitarle su svitka.

_ ¡Así es como te portas! -dijo el pastor-. Igual que un perro, no bien suelto, ¡a morder! ¡Toma pues, granuja! ¡Toma, bandolero!

Y se puso a darle al señor con su látigo. El señor lo soltó e intentó marcharse, pero el pastor le persiguió: un paso y otro, un paso y otro. El señor echó a correr. Quién sabe de dónde le vino esa ligereza en los pies. Corrió hasta no poder más, perdió las últimas fuerzas y quedó tumbado en el camino mismo.

Para su buena fortuna, pasaron caminando por allí algunos viejos mendigos ambulantes. Un viejo se apiadó de él y le ofreció su $s v i t k a^{28}$. El señor se vistió y se marchó con ellos, comiendo lo que le daban de limosna. Mientras caminaba les contó lo que le había sucedido, anunciando cómo les pagaría a los que lo habían ofendido y cómo premiaría a los viejos por abrigarlo y por llevarlo consigo. Los ancianos se pusieron a preparar bolsas nuevas para guardar los cuartos y regalos prometidos. Llegaron hasta el pueblo y fueron a meterse directamente en los aposentos de los señores. Los criados se pusieron a gritar:

— ¿Adónde vais?

- ¡Apartaos! -dijo el señor-. ¿No veis, infames, que viene vuestro señor?

— ¿Qué señor? Teníamos uno, pero ha desaparecido.

— ¡Mentira, bestias! Yo soy vuestro señor.

${ }^{27}$ Lápot, «calzado de corteza trenzada».

${ }^{28}$ Svitka, «abrigo largo». 
-Pues espera un poco, hermano.

El señor se puso a buscar pelea. ¡Pues muy bien! Lo agarraron por los brazos y lo condujeron adonde estaba la señora. Al oír la señora que aquel andrajoso vagabundo se llamaba su marido, montó en cólera, y ordenó que le dieran de latigazos y que fuese enterrado vivo.

Por más que hizo el señor, por más que dio pelea, fue sepultado vivo.

En la iglesia volvieron a leer las palabras tachadas de que «los ricos se empobrecerán y pasarán hambre», y cuando el diácono leía no se oía ya tronar.

\section{Soberbia versus ira, reconciliación versus ruptura}

Llegados al final de nuestro recorrido, solo nos queda hacer unas últimas y rápidas consideraciones acerca del amplio elenco de relatos en cuyas tramas, eventuales vínculos y presuntas analogías (y discrepancias y oposiciones) hemos estado indagando. Saco a colación aquí la idea de «oposición» porque el exemplo 51 de El conde Lucanor me parece que es una condena muy vigorosa del pecado de la soberbia regia, al tiempo que una reivindicación igualmente decidida del concepto de ira divina, mientras que el episodio de la salida al exilio del Cantar de mio Cid me parece una exaltación muy clara del concepto de mesura épica (que es lo contrario de la soberbia) y una condena ferviente de la ira regia ${ }^{29}$. Vistos en esta perspectiva, el soberbio rey juanmanuelino, y el humilde héroe burgalés del Cantar (no el del romance de La jura de Santa Gadea), al que podemos asociar funcionalmente con la humilde y sincera Cordelia -víctimas ambos de injustas y desmesuradas iras regias-, se hallan colocados en posiciones absolutamente opuestas, antitéticas. Si bien ambos extremos coinciden en criticar y en condenar los pecados del rey -ya sea soberbia, ya sea ira- como causa de inestabilidades y detonante de indeseables rupturas del contrato político y social.

Y, sin embargo, todos los conflictos que han ido pasando ante nosotros han acabado en deposición de la ira, en perdón de la soberbia, en reconciliación y devolución de las dignidades expropiadas - excepto en la última leyenda rusa,

\footnotetext{
${ }^{29}$ Sobre la ira regia véanse las consideraciones que hace Montaner en su edición del Cantar de mio Cid, pp. 379-384, que remite a una amplísima bibliografía de estudios anteriores: de Menéndez Pidal, Grassotti, Valdeavellano, Lacarra, Pérez-Prendes, etc. A ellos se podrían sumar los trabajos de Bernard Darbord, «Sobre la expresión de poder en el Poema de Mio Cid», en El Cid: de la materia épica a las crónicas caballerescas, pp. 29-39; José Manuel Pérez y Prendes Muñoz Arraco, «El riepto contra Rodrigo (1089)», en El Cid: de la materia épica a las crónicas caballerescas, pp. 72-83; Ghislaine Fournès, «Un motivo cidiano en la obra de Alfonso X: la ira regia», en El Cid: de la materia épica a las crónicas caballerescas, pp. 286-294; y Ana Rodríguez, «Modelos de legitimidad política en la Chronica regum Castellae de Juan de Osma», en e-Spania: Revue Électronique d'Études Hispaniques Médiévales 2 (2006); y Pedrosa, «Crimen real, ira regia».
} 
que condenaba a muerte al rey soberbio-. Ira y soberbia se nos muestran, así, como pecados reversibles, excusables al cabo del correspondiente trámite penitencial y purificador, como causas de rupturas traumáticas pero no fatales, al final de las cuales espera indefectiblemente la reanudación de las alianzas entre los agentes políticos que sostenían los difíciles equilibrios de la sociedad de entonces. En una época, la de la inestable y conflictiva Edad Media -o la de la inestable y conflictiva sociedad tradicional que reflejan los cuentos folclóricos-, en que tales estrategias de cohesión eran necesarias, en los planos de la política, de las instituciones, de los discursos, de los símbolos, para poder mantener en pie, sin derrocarlas a cada rato, las precarias arquitecturas del poder y garantizar la continuidad y el progreso de la comunidad.

Resulta llamativo que el castigo de otros pecados no fuese tan proclive a encontrar soluciones contemporizadoras en el registro literario e ideológico medieval y tradicional. Recordemos, por ejemplo, los fatídicos castigos -que llegan hasta a la metamorfosis del pecador en piedra o en animal- de la avaricia y la falta de hospitalidad -que es uno de los avatares de la avaricia-que escenifica la abigarrada serie de cuentos que se acoge a la etiqueta ATU 750 (desde el 750 A hasta el ATU 750K**). Fijémonos, en concreto, porque se halla documentado desde la antigüedad hasta el folclore de hoy, y porque está muy bien atestiguado en España, en el cuento-leyenda ATU 750C (God punishes a bad woman: Dios castiga a una mujer mala), que María Jesús Lacarra, en un estudio que aporta información muy profusa acerca de su evolución y paralelos, ha resumido de este modo:

Dentro de la catalogación tipológica de Aarne-Thompson se corresponde con el tipo 750C, cuya síntesis puede ser así: un personaje religioso (Jesucristo, la Virgen), solo o acompañado, se presenta en un pueblo, pidiendo hospitalidad o una limosna. Nadie le presta ayuda, y a veces hasta recibe daño o desprecio por parte de los nativos, salvo de un vecino o una familia que le ofrecen comida. Los desconocidos, en muchas versiones, maldicen a sus habitantes y a sus tierras, pero avisan a sus protectores para que se salven. Al poco tiempo, una catástrofe natural, un gran fuego, una inundación o un diluvio, destruye por completo el lugar, exterminando a todos sus supervivientes, excepto a quienes habían ejercido la caridad con los extraños ${ }^{30}$.

${ }^{30} \mathrm{M}^{\mathrm{a}}$ Jesús Lacarra, «El Camino de Santiago en la literatura contemporánea: el ejemplo de Luis Mateo Díez», en Boletín Hispánico Helvético, 6 (2005), pp. 141-158. Sus notas hacen un repaso exhaustivo de la bibliografía académica que hay sobre esta leyenda. Véanse además Luis L. Cortés y Vázquez, «La leyenda del Lago de Sanabria», en Revista de Dialectología y Tradiciones Populares, IV (1948) pp. 94114; y José Manuel Pedrosa, «Wamba, Ramiro II, Enrique III y Carlos I: relecturas políticas de leyendas medievales en la Edad Moderna (siglos XVIII-XX)», en Memorabilia, 14 (2012) pp. 99-143, pp. 138-139. Conviene señalar que los artículos de Lacarra y Pedrosa, y también el canónico libro de Camarena 
Estamos ante un relato ajeno por completo a la familia narrativa que hemos estado considerando aquí, pero que comparte con ella un elenco muy sugestivo de motivos: de nuevo irrumpe un sujeto venido a menos (un ser sagrado o un ángel en figura de hombre) que pide hospitalidad en una serie de casas, y que es rechazado en todas menos en la última, que será la única que se libre de la destrucción. Resulta inevitable que nos acordemos aquí -aunque las analogías sean casuales, deudoras de adherencias aleatorias de motivos folclóricos flotantes- de los episodios del Cantar de mio Cid o del ciclo narrativo de King Lear en que la alianza del sujeto mendicante pero carismático se establecía solo con la casa-siempre la última- que le daba hospitalidad. Y que tengamos un pensamiento especial para Martín Antolínez, el único burgalés que abrió al Cid excluido la puerta de su casa, y que se vio obligado a abandonar para siempre el que hasta entonces había sido su hogar; pero solo para no quedar manchado por la indignidad en que había caído toda su comunidad y para encaminarse -como hace el anfitrión piadoso del cuento ATU 750C, quien deberá salir también de su casa- hacia un futuro mejor.

Lo que más puede interesarnos ahora es la circunstancia de que mueran fatídicamente todos los que niegan la hospitalidad al mendigo; es decir, de que se decrete la destrucción física total, sin posibilidad de restauración del contrato social, de una comunidad cuando el pecado en que incurre es el de la avaricia, la falta de generosidad, el desprecio al desposeído que pide hospitalidad. Es notable que ni siquiera en este punto podamos librarnos de las reminiscencias -aunque sean lejanísimas o casuales-con los relatos que hemos estado analizando: recuérdese que también las dos hijas avariciosas de Lear -Regan y Goneril-, con sus respectivas huestes y bandos, acabaron borradas del mapa en castigo por la denegación de hospitalidad y dignidad a su padre.

¿De dónde vendrán y por dónde habrán transitado todos estos relatos, y con qué otros se habrán cruzado y contaminado? No lo sabemos. Recordemos que también Odiseo -exiliado y maltratado, por cierto, por haber incurrido en la ira del dios Poseidón-, en los versos finales de su grandiosa epopeya, premió a los deudos y criados que habían sido leales a su recuerdo y fieles al deber de la hospitalidad hacia el mendigo, y condenó a la muerte sin contemplaciones a los que no. Puede que la historia del desposeído - por haber

\footnotetext{
Laucirica y Chevalier, Catálogo tipológico del cuento folklórico español. Cuentos religiosos, núm. 750C (y otros estudios críticos), asocian esta modalidad de relato al tipo ATU 750C (God punishes a bad woman: Dios castiga a una mujer mala). Pero lo cierto es que la coincidencia es imperfecta, y convendría hacer, por ello, en las revisiones futuras de los catálogos tipológicos, las modificaciones correspondientes. El resumen de ATU 750C reza: «Dios castiga a una mujer mala. Un hombre se muestra amable con un mendigo, pero su esposa no. El mendigo concede favores al hombre y le muestra cómo (entre otras cosas) su esposa se ha convertido en vaca».
} 
cometido una falta o pecado contra su superior- que llama con insistencia e incertidumbre a la puerta de la que había sido su casa haya estado siempre ahí, y que los siglos hayan contemplado a muchos hombres entregados a la tarea de narrarla, siempre diferente y siempre parecida.

Recibido: $25 / 04 / 2015$

Aceptado: 31/05/2015

\section{$\cos$}

\section{El eXemplo 51 de El Conde LuCANOR (ATU 757), Mio Cid y King LeaR: SOBERBIA, IRA, Y EL NOBLE AL QUE CIERRAN LAS PUERTAS DE SU CASA}

RESUMEN: El exemplo 51 de El conde Lucanor (ATU 757), el episodio de la salida al destierro del Cantar de Mio Cid, el King Lear de Monmouth y de Shakespeare, y el cuento El amor como la sal (ATU 923) se ajustan a esquemas narrativos parecidos. Sus semejanzas tienen relación con el tratamiento que todas estas obras hacen de los pecados de la soberbia, de la ira y de la negación de la hospitalidad.

Palabras clave: Don Juan Manuel. Conde Lucanor. Cantar de mio Cid. King Lear. Alexándr Afanásiev. Épica. Cuento popular. Pecado. Soberbia. Ira. Hospitalidad.

\section{Exemple 51 of El Conde LUCANOR (ATU 757), Mio CiD AND KinG LEAR: PRIDE, ANGER, AND THE DENIAL OF HOSPITALITY TO THE NOBLEMAN}

ABSTRACT: The exemplo 51 of Count Lucanor (ATU 757), the episode of the departure into exile of Cantar de Mio Cid, King Lear of Monmouth and Shakespeare, and the folktale Love like salt (ATU 923) are literary works that fit narrative and ideological similarities. Their coincidences are related to the treatment that all these works make of the sins of pride, anger and denial of hospitality.

Keywords: Don Juan Manuel. Conde Lucanor. Cantar de mio Cid. King Lear. Alexándr Afanásiev. Epics. Folktale. Sin. Pride. Anger. Hospitality. 